\title{
Black South American
}

National Cancer Institute

\section{Source}

National Cancer Institute. Black South American. NCI Thesaurus. Code C128992.

Denotes a person of African ancestral origins whose family settled in South America. 